\title{
Forest loss and fragmentation in the Amazon: implications for wildlife conservation
}

\author{
William F. Laurance, Heraldo L. Vasconcelos and Thomas E. Lovejoy
}

\begin{abstract}
Amazonian forests are experiencing rapid, unprecedented changes that are having major impacts on wildlife, regional hydrology and the global climate. Rates of deforestation and logging have accelerated in recent years and patterns of forest loss are changing, with extensive new highways providing conduits for settlers and loggers into the heart of the Amazon basin. These myriad changes are causing widespread fragmentation of forests. Fragmented landscapes in the Amazon experience diverse changes in forest dynamics,
\end{abstract}

structure, composition and microclimate, and are highly vulnerable to droughts and fires-alterations that negatively affect a wide variety of animal species. In human-dominated lands intensive hunting may interact synergistically with fragmentation to further threaten wildlife populations.

Keywords Amazon forest, Brazil, deforestation, edge effects, habitat fragmentation, hunting, logging, tropical rain forest, wildlife.

\section{Accelerating forest conversion}

The Amazon basin contains over half of the world's remaining tropical rain forest, and probably sustains more plant and animal species than any other region on earth (Myers \& Myers, 1992). It is also experiencing the world's highest absolute rate of forest destruction (Whitmore, 1997). In Brazilian Amazonia, which encompasses two-thirds of the basin, the pace of forest clearance has accelerated in recent years (Fig. 1), with the area of deforested lands now equalling the total area of France (INPE, 1996, 1998; Schomberg, 1999). Rates of forest loss have also risen sharply in some other parts of the Amazon, such as in Bolivia, Ecuador and Colombia (Laurance, 1998).

Logging operations are also expanding rapidly. To extract valuable timbers, such as mahogany Swietenia spp., loggers bulldoze labyrinths of roads and small clearings in forests, causing collateral tree mortality, soil erosion and compaction, vine and grass invasions, and microclimatic changes associated with disruption

William F. Laurance (corresponding author) Biological Dynamics of Forest Fragments Project, National Institute for Research in the Amazon (INPA), CP 478, Manaus, AM 69011-970, Brazil (fax: + 5592642 2050; e-mail: wfl@inpa.gov.br); and Biodiversity Program, National Museum of Natural History, Smithsonian Institution, Washington, DC 20560, USA.

Heraldo L. Vasconcelos Biological Dynamics of Forest Fragments Project, National Institute for Research in the Amazon (INPA), CP 478, Manaus, AM 69011-970, Brazil.

Thomas E. Lovejoy Counsellor to the Secretary for Biodiversity and Conservation, Smithsonian Institution, Washington, DC 20560, USA.

Received 25 March 1999. Accepted 24 August 1999 of the forest canopy (Uhl \& Vieira, 1989; Johns, 1997). Logged forests are far more accessible to hunters and this can affect drastically some wildlife species. In the Malaysian state of Sarawak, for example, workers at one large logging camp were estimated to consume $33,000 \mathrm{~kg}$ of bush-meat each year (Bennett, 1996). Slashand-burn farmers frequently invade logged areas and convert forests into mosaics of crops and degraded scrub (Johns, 1997).

Logging operations are becoming increasingly international. In recent years multinational timber companies from Malaysia, Indonesia, Taiwan and other Asian countries have moved rapidly into the Amazon. In 1996 alone, Asian companies invested over \$US500 million

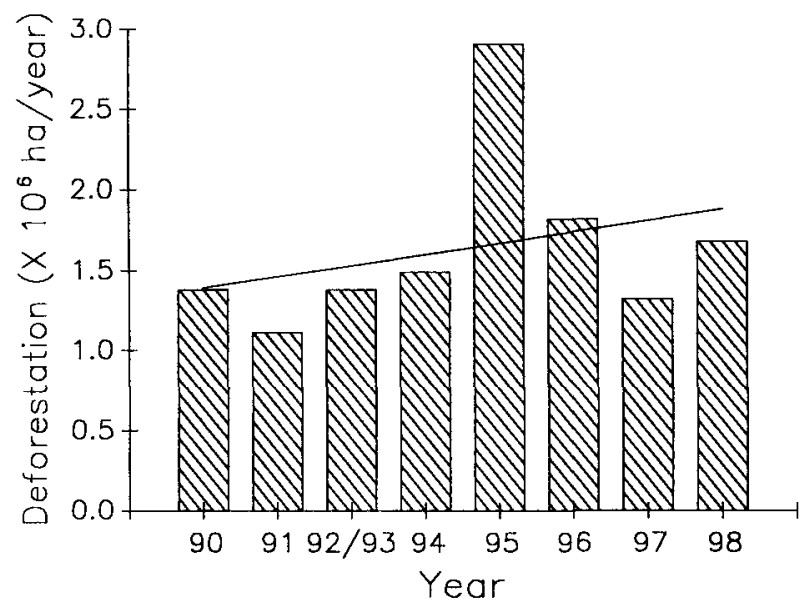

Fig. 1 Rates of deforestation in the Brazilian Amazon since 1990 (a composite rate was estimated for the years 1992 and 1993). Values do not include small ( $<6.25 \mathrm{ha}$ ) clearings or extensive areas degraded by logging or ground fires. The fitted regression line shows the overall trend of increasing deforestation rates this decade. Sources: INPE, 1996, 1998. 
in the Brazilian timber industry, and now own or control at least 12 million ha of Amazonian forest (Laurance, 1998). In addition, there are nearly 400 Brazilian timber companies, most of which have poor environmental records. A government inspection of 34 logging operations in Pará state, for example, concluded that 'the results were a disaster' and that not one was using accepted practices to limit forest damage (Walker, 1996). Indeed, much of the Amazonian timber trade is unregulated: the Brazilian government now estimates that 80 per cent of Amazon timber is harvested illegally, being subjected to no environmental controls whatsoever (Abramovitz, 1998). The explosive growth of Amazonian logging is reflected in Brazil's recent decision to open an additional 14 million ha of its forests to logging (Anon, 1997).

\section{Changing patterns of forest loss}

In addition to rapid forest conversion, the spatial patterns of Amazonian development are changing in unprecedented ways. Since the 1960s, large-scale deforestation has been concentrated in the eastern and southern parts of the basin-in the Brazilian states of Pará, Maranhão, Rondônia, Acre and Mato Grosso, and in northern Bolivia. There has also been some clearing along major rivers and in the western and northern Amazon, particularly in Ecuador, Colombia, Venezuela, Peru and, most recently, in Roraima, Brazil (Laurance, 1998).

Today, however, a bevy of new highways, powerlines and transportation projects are dissecting the heart of the Amazon basin, providing access to areas once considered too remote for settlement or development. One major new highway, BR-174, runs from the city of Manaus in central Amazonia, northward to the Venezuelan border, spanning over $1000 \mathrm{~km}$. Although initially promoted as a 'surgical cut' through the forest to allow access to markets in Venezuela, Brazilian President Cardoso announced in 1997 that 6 million ha of land along the highway would be opened to settlement, and suggested that the area to be farmed was 'so colossal that it will double the nation's agricultural production' (de Cassia, 1997). This highway is already promoting rapid forest clearance, especially near the cities of Manaus and Boa Vista (Laurance, 1998).

The alarming pace of Amazonian development is causing widespread forest fragmentation. In 1988, the area of forest in Brazilian Amazonia that was fragmented (defined as isolated forest tracts of $<100 \mathrm{sq} \mathrm{km}$ in area) or prone to edge effects $(<1 \mathrm{~km}$ from clearings) was over 1.5 times larger than the area actually deforested (Skole \& Tucker, 1993). More than 13 percent of the region has now been deforested

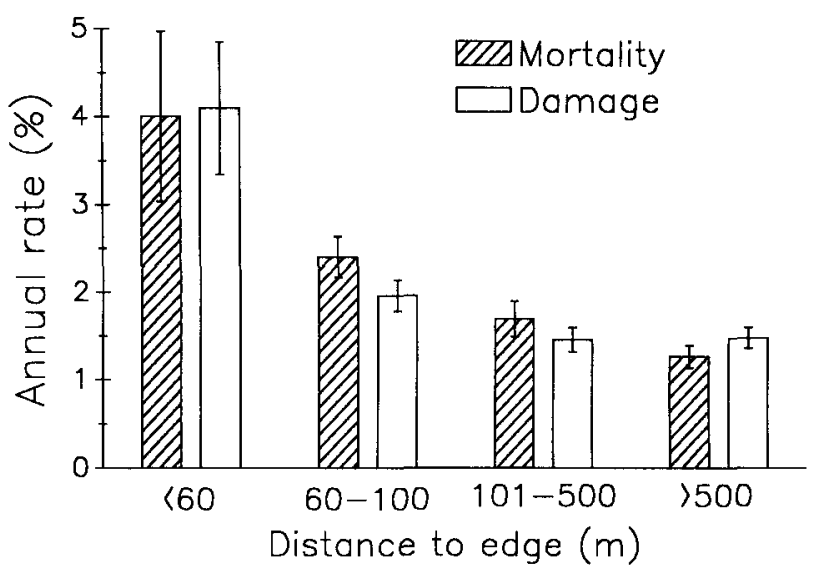

Fig. 2 Annual rates of tree mortality and damage in Amazonian rain forests as a function of distance to the nearest forest edge. Only large ( $\geq 10 \mathrm{~cm}$ diameter at breast height) trees are included in this comparison (Laurance et al., 1998b).

(Schomberg, 1999), and the total area affected by fragmentation, clearing and edge effects could comprise as much as a third of the Brazilian Amazon (Laurance, 1998). These figures do not include the very extensive areas affected by logging and ground-fires, both of which cause important changes in forest ecology (Uhl \& Vieira, 1989; Cochrane et al., 1999) but are not detected by the satellite images used to map Amazon deforestation (Nepstad et al., 1999).

\section{Ecological changes in fragmented landscapes}

Long-term studies, such as the Biological Dynamics of Forest Fragments Project (BDFFP) near Manaus, Brazil (Lovejoy et al., 1986; Bierregaard et al., 1992), are revealing that habitat fragmentation affects the ecology of Amazonian forests in many ways, such as altering the diversity and composition of fragment biotas (Laurance \& Bierregaard, 1997), and changing ecological processes such as nutrient-cycling and pollination (Powell \& Powell, 1987; Klein, 1989; Didham, 1997a). Recent evidence indicates that fragmentation also alters forest dynamics (Fig. 2), causing sharp increases in rates of tree mortality, damage and canopy-gap formation as a result of greater desiccation and wind turbulence near forest edges (Ferreira \& Laurance, 1997; Laurance et al., 1998b).

These changes have pervasive effects on forest ecology, especially within 100-300 m of edges (Laurance et al., 1998b). Pioneer and secondary tree numbers increase sharply in fragments, while old-growth, forestinterior trees decline in number (Benitez-Malvido, 1998; Laurance et al., 1998c). Lianas (woody vines) become more abundant near edges, leading to higher rates of tree infestation and mortality (Laurance, 1991a). 
Increases in canopy gaps in fragments alter forest microclimate (Kapos, 1989; Camargo \& Kapos, 1995) and lead to a proliferation of disturbance-adapted plants in the forest understorey (Laurance, in press).

A further consequence of elevated tree mortality is the loss of living biomass in fragments (Laurance et al., 1997, 1998a, d). As dead trees decompose, they emit greenhouse gases, particularly carbon dioxide and methane. Mathematical models suggest that the loss of biomass from rapid fragmentation of the world's tropical forests could cause the emission of up to 150 million tons of atmospheric carbon annually (Laurance et al., 1998d). These emissions-equivalent to clearing and burning as much as 1.1 million ha of rain forest each year, above and beyond that actually deforested-could contribute significantly to global warming. Such emissions are predicted to increase markedly in fragments under 100-400 ha in area (Laurance et al., 1997, 1998b).

Finally, there are important synergisms between forest fragmentation and natural climatic variability. Because they are prone to desiccation, fragmented forests appear to be far more vulnerable than intact forests to droughts and fires. Fragmentation also causes forest remnants to be juxtaposed with fire-prone pastures, farmlands and regrowth (Kauffman \& Uhl, 1991). A common pattern is for fires lit by farmers and ranchers to penetrate hundreds of metres into nearby forests, often burning only leaf-litter. Although of low intensity, these ground-fires initiate an insidious cycle: they kill some rain-forest trees, creating additional woody debris and openings in the forest canopy. These in turn cause the forest to become drier and more inflammable, making it far more prone to devastating wildfires in the future (Cochrane et al., 1999).

The threat from Amazonian forest fires is clearly increasing (Nepstad et al., 1998, 1999). During the 1997/ $98 \mathrm{El} \mathrm{Niño} \mathrm{drought,} \mathrm{wildfires} \mathrm{ignited} \mathrm{by} \mathrm{farmers} \mathrm{and}$ ranchers swept through over 1 million ha of fragmented, logged and regrowth forest in the northern Brazilian state of Roraima (Barbosa, 1998), with additional wildfires in many other locations (Cochrane \& Schulze, 1998). Over a 4-month period in 1997, satellite images revealed 44,734 separate fires in the Amazon, virtually all of them caused by humans (Brown, 1998). Smoke from burning forest became so severe in Manaus and Boa Vista that the city airports were closed temporarily and local hospitals reported increases of 40-100 per cent in the incidence of respiratory problems (Laurance, 1998).

\section{Implications for wildlife}

Although much remains unknown about these prob- lems, it is apparent that forest fragmentation has myriad effects on Amazonian wildlife. During the past 20 years, BDFFP research has revealed that many faunal groups, such as insectivorous understorey birds, most primates and many larger mammals, decline in abundance or disappear in fragmented forests (Lovejoy et al., 1986; Zimmerman \& Bierregaard, 1986; Rylands \& Keuroghlian, 1988; Schwartzkopf \& Rylands, 1989; Bierregaard et al., 1992; Bierregaard \& Stouffer, 1997; Nelson, 1999). Numerous invertebrate species, such as certain ants, beetles, butterflies and termites, also respond negatively to fragmentation and edge effects (Klein, 1989; Souza \& Brown, 1994; Brown \& Hutchings, 1997; Didham, 1997b; Carvalho \& Vasconcelos, 1999).

Several important trends have been revealed by BDFFP research. First, it is apparent that many animals are strongly influenced by ecological changes in fragments, especially those caused by edge effects (Fig. 3). Given the magnitude of changes in forest dynamics, structure, composition and microclimate, this is perhaps not surprising. Species' responses to edges vary widely, with some groups (e.g. butterflies) being affected as far as $250 \mathrm{~m}$ into the forest (Brown \& Hutchings, 1997).

Second, numerous species, such as many arboreal mammals and understorey birds, are unable or unwilling to cross even small ( $<80 \mathrm{~m}$ wide) forest clearings (Lovejoy et al., 1986; Bierregaard et al., 1992; Bierregaard \& Stouffer, 1997; Laurance \& Laurance, 1999). Even unpaved roads $(30-80-\mathrm{m}$-wide clearings) inhibit the movements of some forest-interior birds, particularly specialized ant-followers (Formicariidae) and small insectivores that forage in mixed-species flocks (S. G. Laurance, pers. comm.). Mathematical simulations suggest that two key traits - an inability to cross clearings and large home-range size-will strongly increase the vulnerability of Amazonian vertebrates to forest fragmentation (Dale et al., 1994).

Third, an increasing body of evidence suggests that species that tolerate or exploit the matrix of modified habitats surrounding fragments - such as cattle pastures and forests regrowth-are likely to persist in fragments, while those that avoid the matrix usually decline or disappear (Laurance, 1991b; Malcolm, 1991; Bierregaard \& Stouffer, 1997; Gascon et al., 1999). This trend is apparent in at least three vertebrate groupsbirds, frogs, and small terrestrial mammals (Gascon et al., 1999)-and probably arises for two reasons: (i) matrix-tolerant species are better able to move among fragments and other forest areas, thereby reducing the deleterious genetic and demographic effects of population isolation; and (ii) matrix-tolerant species have relatively broad habitat tolerances, and thus are less sensitive to the myriad ecological changes in fragments. 
A surprising result of the BDFFP is that a few faunal groups, such as small mammals and frogs, appear quite resilient to fragmentation (Malcolm, 1997; Tocher et al., 1997; de Lima \& Gascon, 1999). The species richness of frogs, for example, actually increases in forest fragments after isolation, largely because of an influx of generalist species that thrive in adjoining regrowth and pastures (Tocher et al., 1997). It must be emphasized, however, that these results may not be typical of other fragmented landscapes, because the BDFFP fragments are still quite young (14-18 years old), often surrounded by regrowth forest and separated only by short distances $(70-1000 \mathrm{~m})$ from very large ( $>1$ million ha) forest tracts. Thus, our findings are probably conservative: the impacts of fragmentation on Amazonian fauna in other localities will be at least as great as those observed here.

The BDFFP experiment is also conservative because the study area is protected from chronic disturbances, such as hunting, logging and major wildfires, which plague many anthropogenic landscapes (Laurance \& Bierregaard, 1997). In the eastern Amazon, where deforestation is particularly severe, many fragments are damaged by logging and fires. A typical 100-ha fragment near Paragominas, Pará, for example, had about half of its area burned in 1995 and 1997. The burned areas supported only dead trees with short, scrubby regrowth in the understorey (W. F. Laurance, pers. obs.).

Hunting pressure is growing throughout the Amazon because of greater access to forests and markets, and the increasing use of shotguns. Commonly exploited species include larger birds and primates, deer, tapirs, peccaries, large rodents and top carnivores such as jaguars Panthera onca and pumas Puma concolor (Peres, 1990; Robinson \& Redford, 1991, 1994; Bodmer et al., 1994; Cullen, 1997). Intensive hunting can extirpate species with low reproductive rates and dramatically alter the species composition of faunal communities (Robinson \& Redford, 1991; Alvard et al., 1997). Such

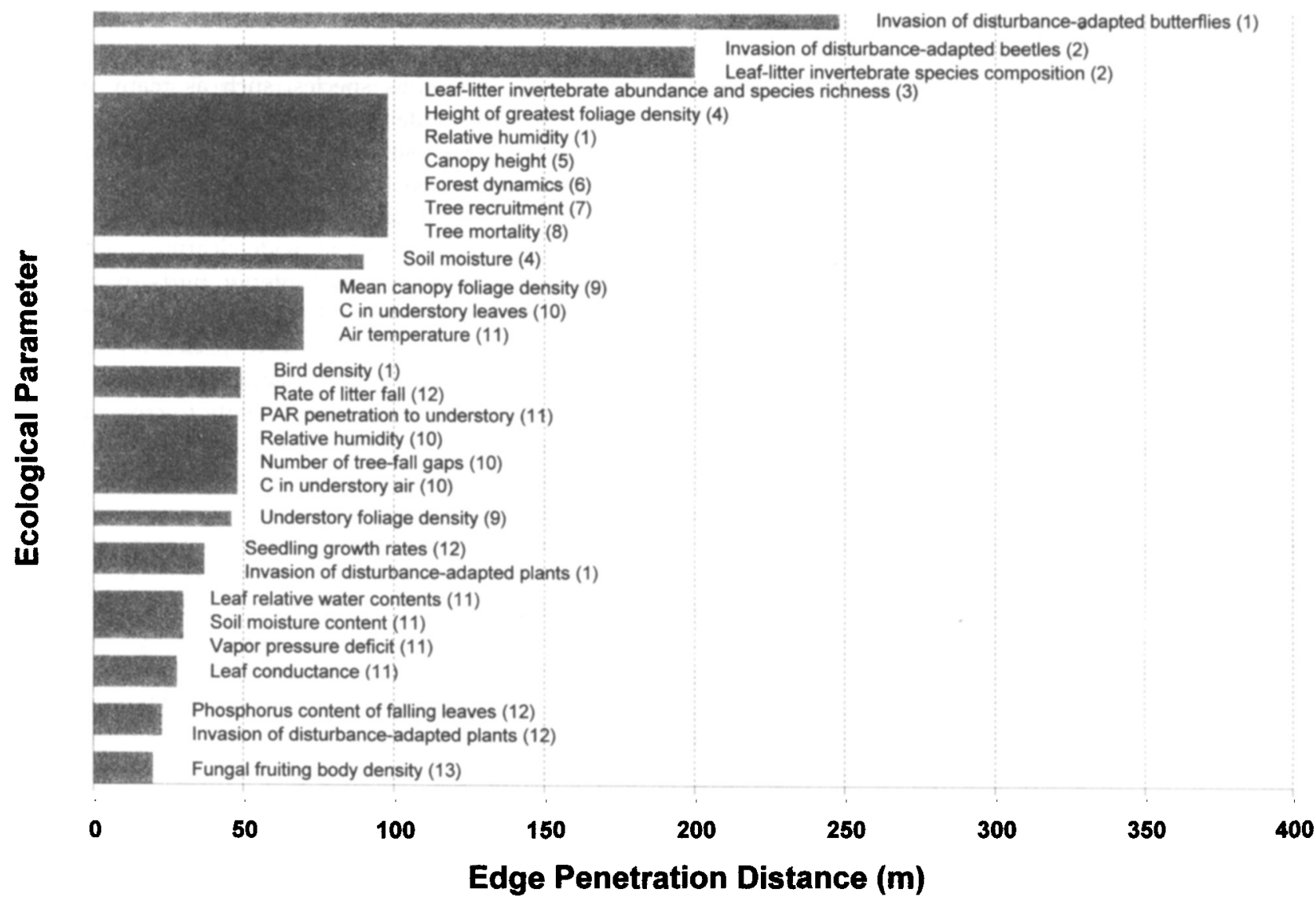

Fig. 3 Different edge effects penetrate to widely varying distances inside rain-forest fragments. Data shown here were collected in central Amazonia, as part of the Biological Dynamics of Forest Fragments Project. Numbers in parentheses indicate data sources (1, Lovejoy et al., 1986; 2, Didham, 1997a, Carvalho \& Vasconcelos, 1999; 3, Didham, 1997b; 4, Camargo \& Kapos, 1995; 5, Camargo, 1993; 6, Laurance et al., 1998b; 7, Laurance et al., 1998c; 8, Ferreira \& Laurance, 1997; 9, Malcolm, 1994; 10, Kapos et al., 1993; 11, Kapos, 1989; 12, Bierregaard et al., 1992; 13, R. K. Didham, pers. comm.). 
changes are likely to have especially dire consequences in fragmented landscapes, where wildlife populations are often small, isolated and vulnerable to overharvesting (Cullen, 1997; Woodroffe \& Ginsberg, 1998; Chiarello, 1999).

\section{Future prospects for the Amazon}

Conservation in the Amazon is an uphill battle. The population of the Brazilian Amazon has increased tenfold since the early 1960s, from about 2 million to 20 million people, accompanied by an equally dramatic rise in major transportation, logging, mining and infrastructure projects (Laurance, 1998). Since 1988, control of Amazonian resources has been progressively shifting from the Brazilian federal government to state and municipal authorities, which are poorly qualified to meet this challenge and prone to local development pressures. In addition, Amazonian nations have traditionally viewed the basin as a source of wealth, and have often regarded foreign initiatives to promote forest conservation with suspicion and ambivalence (Laurance \& Fearnside, 1999).

Several international and domestic programmes have the potential to improve Amazonian conservation, but all face daunting challenges. Stronger environmental legislation was recently enacted in Brazil, but its implementation has been obstructed by executive and congressional interference, which have rendered it virtually powerless (Laurance, 1999). Despite such hindrances, Brazil's national environment agency, IBAMA (Instituto Brasileiro do Meioambiente e dos Recursos Naturis Renováveis), isnowenlistingthehelpofthe army-

to patrol the Amazon for illegal logging, mining and deforestation.

The most important international initiative is the Pilot Program to Conserve the Brazilian Rainforest (Anon, 1999). Administered by the World Bank, the Pilot Program is attempting to channel about \$US350 million from Germany, the European Community, Britain and other major industrial nations into Amazonian conservation programmes. The Program embodies many good ideas-land-use planning, extractive and Amerindian reserves, ecological corridor systems, applied research, and capacity-building for local governments, among others. It has been particularly successful in fostering the creation of new nongovernmental organizations, many of which are oriented towards sustainable development or indigenous communities, and in promoting the designation of Amerindian reserves (Laurance \& Fearnside, 1999).

The Pilot Program faces major obstacles, however, and nearly collapsed in early 1999 when Brazil withdrew its own contributions to the programme, which total about a tenth of the overall budget. Under intense international and domestic pressure, the Brazilian government later reversed this decision. Although Brazil's actions were precipitated by its recent economic crisis, its wavering support for Amazonian conservation has raised serious concerns in many quarters (Laurance \& Fearnside, 1999).

If there is any reason for optimism, it is that local support for conservation appears to be growing in the Amazon. Today there are about 350 indigenous and environmental groups in Brazil (Anon, 1999). These grassroots organizations provide some hope for the future, but there is not the slightest room for complacency. For unless present trends are altered, the Amazon and its wildlife will be massively diminished in the years to come.

\section{Acknowledgements}

We thank Claude Gascon, Richard Bierregaard and three anonymous referees for commenting on drafts of the manuscript, and Susan G. Laurance for granting access to her unpublished data. Support was provided by the Smithsonian Institution, National Institute for Research in the Amazon, US National Science Foundation, Wildlife Conservation Society, NASA Long-term Biosphere-Atmosphere Experiment in the Amazon, and Brazilian national science agency (CNPq). This is publication number 254 in the BDFFP technical series.

\section{References}

Abramovitz, J. (1998) Taking a Stand: Cultivating a New Relationship with the World's Forests. World Watch Institute, Washington, DC.

Alvard, M.S., Robinson, J.G., Redford, K.H. \& Kaplan, H. (1997) The sustainability of subsistence hunting in the neotropics. Conservation Biology, 11, 977-982.

Anon (1997) Controle sobre florestas exige a reforma do IBAMA, 1997. A Critica. Manaus, Brazil, 19 January.

Anon (1999) Pilot Program to Conserve the Brazilian Rain Forest: Annual Report on Progress. World Bank, Brasilia, Brazil.

Barbosa, R.I. (1998) Avaliação Preliminar da Área dos Sistemas Naturais e Agroecossistemas Atingida por Incêndios no Estado de Roraima (10.12.1997 a 30.04.98). Instituto Nacional de Pesquisas da Amazônia e Nucleo de Pesquisas de Roraima, Boa Vista, Roraima, Brazil.

Benitez-Malvido, J. (1998) Impact of forest fragmentation on seedling abundance in a tropical rain forest. Conservation Biology, 12, 380-389.

Bennett, E.L. (1996) The inter-relationships of commercial logging, hunting, and wildlife in Sarawak, and recommendations for forest management. In Effects of Logging on Wildlife in the Tropics (proceedings of a conference sponsored by BOLFOR [Bolivia] and Wildlife Conservation 
Society [New York]), p. 16. Wildlife Conservation Society, Bronx, NY.

Bierregaard, R.O. Jr., Lovejoy, T.E., Kapos, V., dos Santos, A.A. \& Hutchings, R.W. (1992) The biological dynamics of tropical rainforest fragments. Bioscience, 42, 859-866.

Bierregaard, R.O. Jr. \& Stouffer, P. (1997) Understory birds and dynamic habitat mosaics in Amazonian rainforests. In Tropical Forest Remnants: Ecology, Management, and Conservation of Fragmented Communities (eds W. F. Laurance and R. O. Bierregaard Jr.), pp. 138-155. University of Chicago Press, Chicago, IL.

Bodmer, R.E., Fang, T.G., Moya, L. \& Gill, R. (1994) Managing wildlife to conserve Amazonian forests: population biology and economic considerations of game hunting. Biological Conservation, 67, 29-35.

Brown, K.S. \& Hutchings, R.W. (1997) Disturbance, fragmentation, and the dynamics of diversity in Amazonian forest butterflies. In Tropical Forest Remnants: Ecology, Management, and Conservation of Fragmented Communities (eds W. F. Laurance and R. O. Bierregaard Jr.), pp. 91-110. University of Chicago Press, Chicago, IL.

Brown, P. (1998) Forest fires: setting the world ablaze. The Guardian, London, 20 March.

Camargo, J.L. (1993) Variation in soil moisture and air vapour pressure deficit relative to tropical rain forest edges near Manaus, Brazil. MPhil Thesis, Cambridge University, UK.

Camargo, J.L. \& Kapos, V. (1995) Complex edge effects on soil moisture and microclimate in central Amazonian forest. Journal of Tropical Ecology, 11, 205-211.

Carvalho, K. \& Vasconcelos, H.L. (1999) Forest fragmentation in central Amazonia and its effects on litter-dwelling ants. Biological Conservation, 91, 151-157.

de Cassia, R. (1997) BR-174: FHC anuncia abertura de nova frontiera agricola no norte. p. A-4. Amazonas em Tempo, Manaus, Brazil, 25 June.

Chiarello, A.G. (1999) Effects of fragmentation of the Atlantic forest on mammal communities in south-eastern Brazil. Biological Conservation, 89, 71-82.

Cochrane, M.A., Alencar, A., Schulze, M.D., Souza, C.M., Nepstad, D.C., Lefebvre, P. \& Davidson, E.A. (1999) Positive feedbacks in the fire dynamics of closed canopy tropical forests. Science, 284, 1832-1835.

Cochrane, M.A. \& Schulze, M.D. (1998) Forest fires in the Brazilian Amazon. Conservation Biology, 12, 948-950.

Cullen, L. Jr. (1997) Hunting and biodiversity in Atlantic forest fragments, São Paulo, Brazil. MA Thesis, University of Florida, Gainesville, FL.

Dale, V.H., Pearson, S.M., Offerman, H.L. \& O'Neill, R.V. (1994) Relating patterns of land-use change to faunal biodiversity in the central Amazon. Conservation Biology, 8, 1027-1036.

Didham, R.K. (1997a) An overview of invertebrate responses to habitat fragmentation. In Forests and Insects (eds A. Watt, N. E. Stork and M. Hunter), pp. 201-218. Chapman and Hall, London, UK.

Didham, R.K. (1997b) The influence of edge effects and forest fragmentation on leaf-litter invertebrates in central Amazonia. In Tropical Forest Remnants: Ecology, Management, and Conservation of Fragmented Communities (eds W. F. Laurance and R. O. Bierregaard Jr.), pp. 55-70. University of Chicago Press, Chicago, IL.
Ferreira, L.V. \& Laurance, W.F. (1997) Effects of forest fragmentation on mortality and damage of selected trees in central Amazonia. Conservation Biology, 11, 797-801.

Gascon, C., Lovejoy, T.E., Bierregaard, R.O., Malcolm, J.R., Stouffer, P.C., Vasconcelos, H.L. et al. (1999) Matrix habitat and species persistence in tropical forest remnants. Biological Conservation, 91, 223-229.

Johns, A.G. (1997) Timber Production and Biodiversity Conservation in Tropical Rain Forests. Cambridge University Press, Cambridge, UK.

INPE (1996) Deforestation Estimates in the Brazilian Amazon, 1992-1994. Instituto Nacional de Pesquisas Espaciais, San Jose dos Campos, Brazil.

INPE (1998) Deforestation Estimates in the Brazilian Amazon, 1995-1997. Instituto Nacional de Pesquisas Espaciais, San Jose dos Campos, Brazil.

Kapos, V. (1989) Effects of isolation on the water status of forest patches in the Brazilian Amazon. Journal of Tropical Ecology, 5, 173-185.

Kapos, V., Ganade, G., Matsui, E. \& Victoria, R.L. (1993) ${ }^{13} \mathrm{C}$ as an indicator of edge effects in tropical rain forest fragments. Journal of Tropical Ecology, 8, 425-432.

Kauffman, J.B. \& Uhl, C. (1991) Interactions of anthropogenic activities, fire, and rain forests in the Amazon Basin. In Fire in the Tropical Biota (ed. J. G. Goldammer), pp. 117-134. Springer-Verlag, New York.

Klein, B.C. (1989) Effects of forest fragmentation on dung and carrion beetle communities in central Amazonia. Ecology, 70, 1715-1725.

Laurance, W.F. (1991a) Edge effects in tropical forest fragments: application of a model for the design of nature reserves. Biological Conservation, 57, 205-219.

Laurance, W.F. (1991b) Ecological correlates of extinction proneness in Australian tropical rain forest mammals. Conservation Biology, 5, 79-89.

Laurance, W.F. (1998) A crisis in the making: responses of Amazonian forests to land use and climate change. Trends in Ecology and Evolution, 13, 411-415.

Laurance, W.F. (1999) Reflections on the tropical deforestation crisis. Biological Conservation, 91, 109-117.

Laurance, W.F. (in press) Fragmentation and plant communities: synthesis and implications for landscape management. In Lessons from Amazonia: Ecology and Conservation of a Fragmented Forest (eds R. O. Bierregaard, C. Gascon, T. Lovejoy and R. Mesquita). Yale University Press, New Haven, CT.

Laurance, W.F. \& Bierregaard, R O. Jr. (eds) (1997) Tropical Forest Remnants: Ecology, Management and Conservation of Fragmented Communities. University of Chicago Press, Chicago, IL.

Laurance, W.F. \& Fearnside, P.M. (1999) Amazon burning. Trends in Ecology and Evolution, 14, 457.

Laurance, S.G.W. \& Laurance, W.F. (1999) Tropical wildlife corridors: use of linear rainforest remnants by arboreal mammals. Biological Conservation, 91, 231239.

Laurance, W.F., Ferreira, L.V., Gascon, C. \& Lovejoy, T.E. (1998a) Biomass loss in Amazonian forest fragments. Science, 282, 1611a.

Laurance, W.F., Ferreira, L.V., Rankin-de Merona, J.M. \& Laurance, S.G. (1998b) Rain forest fragmentation and the 
dynamics of Amazonian tree communities. Ecology, 79, 2032-2040.

Laurance, W.F., Ferreira, L.V., Rankin-de Merona, J.M., Laurance, S.G., Hutchings, R. \& Lovejoy, T.E. (1998c) Effects of forest fragmentation on recruitment patterns in Amazonian tree communities. Conservation Biology, 12, 460-464.

Laurance, W.F., Laurance, S.G. \& Delamonica, P. (1998d) Tropical forest fragmentation and greenhouse gas emissions. Forest Ecology and Management, 110, 173-180

Laurance, W.F., Laurance, S.G., Ferreira, L.V., Rankin-de Merona, J.M., Gascon, C. \& Lovejoy, T.E. (1997) Biomass collapse in Amazonian forest fragments. Science, 278, 1117-1118.

de Lima, M.G. \& Gascon, C. (1999) The conservation value of linear forest remnants in central Amazonia. Biological Conservation, 91, 241-247.

Lovejoy, T.E., Bierregaard, R.O. Jr., Rylands, A.B., Malcolm, J.R., Quintela, C.E., Harper, L.H. et al. (1986) Edge and other effects of isolation on Amazon forest fragments. In Conservation Biology: The Science of Scarcity and Diversity (ed. M. E. Soule), pp. 257-285. Sinauer, Sunderland, MA.

Malcolm, J.R. (1991) The small mammals of Amazonian forest fragments: pattern and process. PhD Thesis, University of Florida, Gainesville, FL.

Malcolm, J.R. (1994) Edge effects in central Amazonian forest fragments. Ecology, 75, 2438-2445.

Malcolm, J.R. (1997) Biomass and diversity of small mammals in forest fragments. In Tropical Forest Remnants: Ecology, Management, and Conservation of Fragmented Communities (eds W. F. Laurance and R. O. Bierregaard Jr.), pp. 207-221. University of Chicago Press, Chicago, IL.

Myers, N. \& Myers, N.J. (1992) The Primary Source: Tropical Forests and Our Future-Updated for the 1990s. W. W. Norton and Company, New York.

Nelson, L. (1999) Efeitos de borda e do crescimento secundário sobre pequenos mamiferos nas florestas de terra firme da Amazônia central. MSc Thesis, National Institute for Research in the Amazon (INPA), Manaus, Brazil.

Nepstad, D.C., Verissimo, A., Alencar, A., Nobre, C., Lima, E., Lefebre, P. et al. (1999) Large-scale impoverishment of Amazonian forests by logging and fire. Nature, 398, 505-508.

Nepstad, D.C., Moreira, A., Verissimo, A., Lefebvre, P., Schlesinger, P., Potter, C. et al. (1998) Forest fire prediction and prevention in the Brazilian Amazon. Conservation Biology, 12, 951-955.

Peres, C.A. (1990) Effects of hunting on western Amazonian primate communities. Conservation Biology, 4, 47-59.

Powell, A.H. \& Powell, G.V.N. (1987) Population dynamics of male euglossine bees in Amazonian forest fragments. Biotropica, 19, 176-179.

Robinson, J.G. \& Redford, K.H. (eds) (1991) Neotropical Wildlife Use and Conservation. University of Chicago Press, Chicago, IL.

Robinson, J.G. \& Redford, K.H. (1994) Measuring the sustainability of hunting in tropical forests. Oryx, 28, 249-256.

Rylands, A.B. \& Keuroghlian, A. (1988) Primate populations in continuous forest and forest fragments in central Amazonia. Acta Amazonia, 19, 291-307.
Schomberg, W. (1999) Deforestation in Brazil's Amazon jumps in 1998. Reuters News Service, 11 February.

Schwartzkopf, L. \& Rylands, A.B. (1989) Primate species richness in relation to habitat structure in Amazonian rainforest fragments. Biological Conservation, 48, 1-12.

Skole, D. \& Tucker, C.J. (1993) Tropical deforestation and habitat fragmentation in the Amazon: satellite data from 1978 to 1988. Science, 260, 1905-1910.

Souza, de, O.F.F. \& Brown, V.K. (1994) Effects of habitat fragmentation on Amazonian termite communities. Journal of Tropical Ecology, 10, 197-206.

Tocher, M., Gascon, C. \& Zimmerman, B. (1997) Fragmentation effects on a central Amazonian frog community: a ten-year study. In Tropical Forest Remnants: Ecology, Management, and Conservation of Fragmented Communities (eds W. F. Laurance and R. O. Bierregaard Jr.), pp. 124-137. University of Chicago Press, Chicago, IL.

Uhl, C. \& Vieira, I.C.G. (1989) Ecological impacts of selective logging in the Brazilian Amazon: a case study from the Paragominas region of the state of Para. Biotropica, 21, 98-106.

Walker, G. (1996) Kinder cuts. New Scientist, 151 (2048), 40-42.

Whitmore, T.C. (1997) Tropical forest disturbance, disappearance, and species loss. In Tropical Forest Remnants: Ecology, Management, and Conservation of Fragmented Communities (eds W. F. Laurance and R. O. Bierregaard Jr.), pp. 3-12. University of Chicago Press, Chicago, IL.

Woodroffe, R. \& Ginsberg, J.R. (1998) Edge effects and the extinction of populations inside protected areas. Science, 280, 2126-2128.

Zimmerman, B.L. \& Bierregaard, R.O. Jr. (1986) Relevance of the equilibrium theory of island biogeography and species-area relations to conservation, with a case from Amazonia. Journal of Biogeography, 13, 133-143.

\section{Biographical sketches}

William Laurance is a research scientist at the Biological Dynamics of Forest Fragments Project (BDFFP), and a research associate at the Smithsonian Institution. His research interests concern the effects of habitat fragmentation, logging and climatic change on tropical ecosystems. $\mathrm{He}$ is the author of several books and over 100 technical and popular articles.

Heraldo Vasconcelos is the director of the BDFFP and a former chair of the Ecology Department at Brazil's National Institute for Research in the Amazon. His research is focused on the ecology of ant communities, especially in terms of ant-plant interactions and their responses to forest fragmentation.

Thomas Lovejoy is a leading advisor on biodiversity issues to the Smithsonian Institution and the World Bank. He is the founder of the BDFFP and has been actively involved in Amazonian conservation issues for the past three decades. He has produced numerous books and articles and is a board member for many scientific and conservation organizations. 